\title{
ANALISIS PENGARUH TECHNO-FINANCE LITERACY DAN PRAKTIK ENTREPRENEUR RISK MANAGEMENT TERHADAP KINERJA USAHA KECIL MENENGAH (UKM) DI KABUPATEN LOMBOK BARAT
}

\section{Ni Luh Debby M.E.P1, I Nyoman Nugraha AP2 ${ }^{2}$ Embun Suryani ${ }^{3}$}

${ }^{1}$ Faculty of Economics and Business, University of Mataram, Indonesia.

2Program Studi Manajemen Fakultas Ekonomi dan Bisnis Universitas Mataram

Coressponding author: embunsuryani@unram.ac.id

\begin{tabular}{|c|c|}
\hline ARTICLE INFO & ABSTRACT \\
\hline $\begin{array}{l}\text { Keywords: } \\
\text { Financial Literacy, Technology Literacy, } \\
\text { ERM Practices, and SME Performance } \\
\text { Kata Kunci: } \\
\text { Literasi Keuangan, Literasi Teknologi, } \\
\text { Praktik ERM, dan Kinerja UKM } \\
\text { How to cite: } \\
\text { Putri, Ni Luh Debby M.E., Putra, I } \\
\text { Nyoman Nugraha A., Suryani, Embun. } \\
\text { (2022). Analisis Pengaruh Techno-Finance } \\
\text { Literacy Dan Praktek Entrepreneur Risk } \\
\text { Management Terhadap Kinerja Usaha Kecil } \\
\text { Menengah (UKM) Di Kabupaten Lombok } \\
\text { Barat. JMM UNRAM, 11(1), 79-89 } \\
\text { DOI: } \\
\text { 10.29303/jmm.v11i1.705 } \\
\text { Dikumpulkan : } 16 \text { Februari } 2022 \\
\text { Direvisi : 17 Februari } 2022 \\
\text { Dipublikasi : 23 Februari } 2022\end{array}$ & $\begin{array}{l}\text { This study aims to examine the Analysis of the Effect } \\
\text { of Techno-Finance Literacy and Entrepreneurial Risk } \\
\text { Management Practices on the Performance of SMEs } \\
\text { in West Lombok. This study belongs to associative } \\
\text { research with a quantitative research. The population } \\
\text { in this study was } 366 \text { SMEs. This study employed a } \\
\text { purposive sampling technique. It determined the } \\
\text { sample into } 50 \text { SMEs. The data collection method } \\
\text { used in this research is the survey sample method to } \\
\text { collect the data. The variables in this study are } \\
\text { Financial Literacy, Technology Literacy, ERM } \\
\text { Practices, and SME Performance. This study } \\
\text { employed multiple linear regressions using SPSS to } \\
\text { analyze the data. The results indicated that Financial } \\
\text { Literacy and Technological Literacy had a positive } \\
\text { and insignificant effect on the performance of SMEs, } \\
\text { while ERM practices had a positive and significant } \\
\text { effect on the performance of SMEs. } \\
\text { Penelitian ini bertujuan untuk menguji Analisis } \\
\text { Pengaruh Techno-Finance Literacy dan Praktik } \\
\text { Entrepreneur Risk Management Terhadap } \\
\text { Kinerja UKM di Kabupaten Lombok Barat. Jenis } \\
\text { penelitian yang digunakan dalam penelitian ini } \\
\text { adalah penelitian asosiatif dengan pendekatan } \\
\text { kuantitatif. Populasi pada penelitian ini } \\
\text { sebanyak } 366 \text { UKM. Sampel dalam penelitian ini } \\
\text { diperoleh dengan menggunakan teknik } \\
\text { purposive sampling, sehingga jumlah sampel } \\
\text { ditentukan sebanyak } 50 \text { pelaku UKM. Metode } \\
\text { pengumpulan data yang digunakan pada } \\
\text { penelitian ini adalah sampel survey. Variabel } \\
\text { dalam penelitian ini adalah Literasi Keuangan, } \\
\text { Literasi Teknologi dan Praktik ERM. Analisis } \\
\text { data vang digunakan regresi linier berganda }\end{array}$ \\
\hline
\end{tabular}




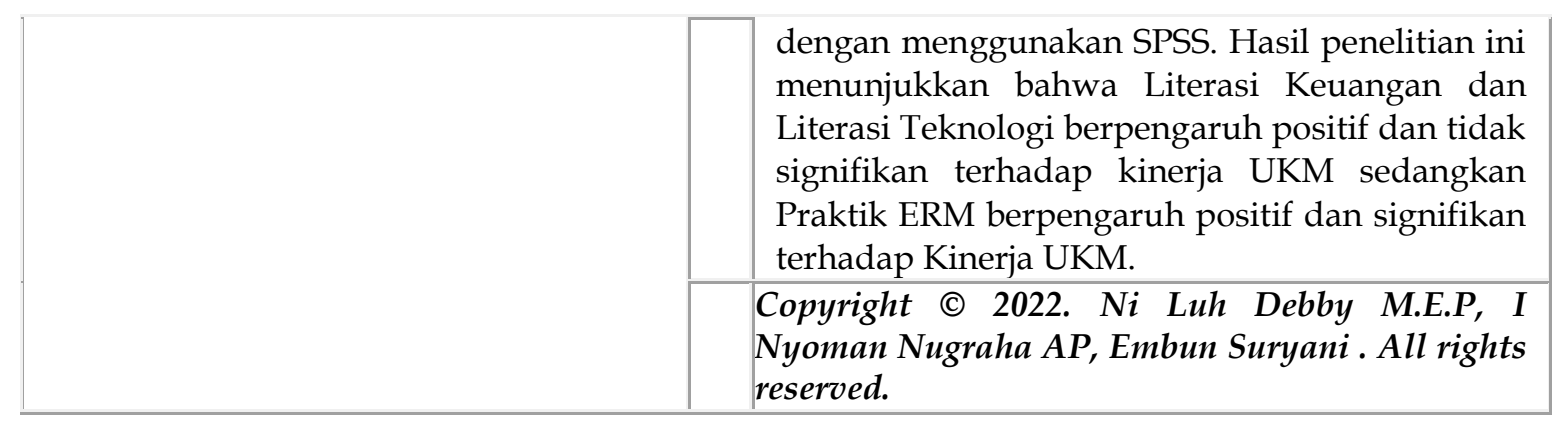

\section{PENDAHULUAN}

Usaha Kecil dan Menengah (UKM) merupakan sebuah mesin yang signifikan untuk memacu kemajuan ekonomi suatu negara (Bititci, 2009). UKM selalu diilustrasikan dengan sektor yang memiliki peran signifikan, karena penduduknya sebagian besar pendidikannya rendah dan hidup dalam aktivitas usaha kecil dan menengah baik di sektor tradisional maupun modern dan dapat menyerap berbagai tenaga kerja (Kuncoro, 2002). Untuk itu sangat penting selalu mengembangkan UKM baik secara kuantitas maupun kualitas, terutama dalam meningkatkan kinerjanya agar dapat memberi kontribusi terhadap pembangunan ekonomi.

Kinerja pada UKM di Indonesia dikatakan masih cukup rendah sehingga membuat Usaha Kecil dan Menengah (UKM) belum bisa berkompetisi dengan usaha lain dan berkembang (Sanistasya, 2019). Kondisi seperti ini yang membuat UKM menjadi tidak stabil dan kurang bisa berkembang dengan baik. Hal yang bisa dilaksanakan adalah dengan meningkatkan keahlian pelaku UKM dalam pengetahuan mengenai pemasaran, finansial, dan teknologi sehingga manajemen dan akuntabilitynya dapat dipertanggungjawabkan sebagaimana layaknya perusahaan besar dengan lebih baik (Nasution, 2014).

Kinerja UKM dapat diukur dengan cara melihat dari sisi kinerja finansial dan non finansialnya. Kinerja finansial adalah suatu kajian yang dilaksanakan agar melihat sejauh mana suatu organisasi telah melakukan dengan menerangkan aturan penerapan finansial secara benar dan baik (Fahmi, 2011:2). Sedangkan kinerja non finansial adalah kinerja yang menerapkan perkembangan dari sebuah organisasi, dimana organisasi dapat memahami tajuk keberhasilannya dari perusahaan dengan menetapkan kajian kinerja non keuangannya.

Menurut Baswir (2010:56) faktor yang mempengaruhi naik turunnya kinerja UKM adalah sekitar $60 \%$ dari usaha kecil yang masih memakai teknologi yang tradisional dan pasarnya juga cenderung dalam kategori menurun dikarenakan modal asset yang masih kurang. Dari usaha kecil juga sebagian besar belum bisa untuk mengkover administrasi agar mendapat dana dari Bank serta tingkat keterikatan terhadap sarana dari pemerintah masih dalam kategori besar. Dari pernyataan diatas didukung penelitian oleh Aribawa (2016) dimana menyatakan bahwa perkembangan kinerja dari jangka panjang suatu UKM masih dalam kategori rendah dan belum tertata. Walaupun jumlah dari suatu UKM meningkat tetapi belum diimbangi dengan meningkatnya mutu dari suatu UKM. Barbara (2000) juga menyatakan bahwa problematika dari bidang manajemen yaitu dalam finansial, pemasaran, dan teknologi sangat mempengaruhi terhadap perkembangan kinerja dari UKM.

Dalam menerapkan suatu usaha, seorang individu diharuskan untuk mempunyai pengetahuan dan kemampuan mengenai finansial untuk mengendalikan finansial dengan efisien dan efektif, karena itu literasi keuangan signifikan bagi suatu usahawan. Literasi 
keuangan merupakan pengetahuan tentang finansial dan produknya yang diterapkan seorang individu dalam finansialnya untuk membuat suatu keputusan berlandaskan informasi mengenai bagaimana cara untuk mengatur finansialnya (Amisi, 2012). Mempunyai kemampuan literasi keuangan dapat membuat seseorang agar membuat keputusan berlandaskan informasi mengenai finansial mereka dan meminimalisir kemungkinan disesatkan dalam problematika finansialnya (Singh, 2018).

Menurut Silalahi (2016:17) indikator untuk mengukur literasi keuangan adalah pemahaman mengenai finansial, pinjaman dan tabungan, investasi, dan asuransi. Indikator tersebut mencakup knowledge, skill, attitude dan behavior dalam mengukur literasi keuangan. Meningkatnya pengetahuan pelaku UKM dalam mengelola keuangan secara benar dan baik maka dapat mempengaruhi kinerja UKM maka dari itu pelaku usaha dapat meningkatkan usaha mereka dengan berkelanjutan secara baik dan benar. Hal tersebut dipertegas dengan penelitian terdahulu yang dilakukan oleh Aribawa (2016) dan Anggraeni (2015) yang menyimpulkan bahwa literasi keuangan berpengaruh pada kinerja UMKM.

Demikian pula, literasi teknologi adalah pemahaman dalam mengatur, memahami, menggunakan serta menilai suatu gebrakan yang mempengaruhi ilmu dalam pengetahuan serta proses untuk menanggulangi suatu problematika dan memperluas pemahaman dari individu. Untuk UKM, literasi teknologi dapat dijadikan sumber pengetahuan yang sangat penting untuk mereka mengembangkan bisnis secara global (Osano, 2019). Menurut Maflikhah (2010) indikator dari teknologi informasi ada dua yakni kemanfaatan dan efektivitas. Kemanfaatan meliputi menjadi pekerjaan lebih mudah, bermanfaat dan menambah efektivitas. Sedangkan efektivitas meliputi mempertinggi efektifitas dan menambah produktivitas. Indikator tersebut mencakup infrastruktur dan aplikasi Teknologi Informasi dan Komunikasi. Maka dari itu, penggabungan literasi keuangan dan teknologi sangat penting untuk memajukan kinerja organisasi atau perusahaan. Hal diatas mendukung penelitian penelitian Ilarrahmah dan Susanti (2019) yang menerangkan bahwa penggunaan teknologi informasi berpengaruh positif terhadap kinerja UMKM.

Menurut Hery (2015) dalam bukunya menjelaskan bahwa Enterpreneur Risk Management adalah suatu proses terstruktur dan berkelanjutan yang dirancang serta dijalankan oleh suatu manajemen. Hal tersebut untuk mewariskan kepercayaan yang layak bahwa seluruh resiko yang diperkirakan memberi dampak yang negatif telah dikelola sebaik mungkin sesuai dengan tingkat resiko yang bersedia diambil suatu perusahaan. Manajemen resiko berpengaruh terhadap kinerja karena melibatkan aktivitas dalam merancang, menyusun, menyinkronasikan, dan mengevaluasi terutama dalam strategi menanggulangi risiko (Djojosoedarso, 2003:4).

Dengan adanya literasi teknologi dan keuangan, akan ada tantangan risiko yang dihadapi pelaku usaha sehingga dapat menyebabkan kerugian dalam suatu perusahaan. Selain itu, risiko tersebut tidak dapat diprediksi kapan akan terjadi dan pasti akan memberikan dampak negatif bagi perusahaan. Maka dari itu praktik Enterprises Risk Management (ERM) adalah salah satu cara untuk meminimalisir terjadinya risiko yang memberikan dampak negatif tersebut. Hal diatas didukung oleh penelitian Kulathunga, dkk (2020) yang menyatakan Entrepreneur Risk Management berpengaruh positif terhadap kinerja UKM.

Keadaan pandemi COVID-19 telah memukul banyak sektor usaha yang membuat sebagian besar pelaku Usaha Kecil dan Menengah (UKM) menjadi terpuruk. Belum bangkit dari dampak gempa, Lombok Barat juga harus ikut kena imbas dari COVID-19. Kedua pukulan itu diakui benar-benar memberatkan bagi sebagian besar masyarakat. 
Seperti daerah yang lain, Lobar juga menjadi sepi dadakan diakibatkan pandemi ini (Aulia, 2020). Ditengah perlambatan yang terjadi, Dinas Koperasi dan UKM Lombok Barat melakukan penataan internal pelaku UKM dengan mengadakan pelatihan kewirausahaan (Dhea, 2021). Bukan hanya penguatan dalam UKM, Diskop Lombok Barat juga terus berupaya untuk memberikan modal dan meningkatkan UKM dengan mengusulkan bantuan dana sebesar 2,4 juta (Her, 2020). Walau sampai sekarang kondisi pariwisata sangat jauh di dibawah daya tampung, Lobar optimis bahwa sektor itu segera kembali membaik dengan kebiasaan yang baru.

Peneliti memilih objek UKM karena menarik untuk dibahas terutama dari pemahaman mengenai techno-finance literacy, dan juga objek UKM disini relevan dengan topik Entrepreneur Risk Management yang akan peneliti bahas. Disamping itu literasi keuangan dan literasi teknologi merupakan pendukung yang memiliki peran penting dalam meningkatkan kinerja UKM. Namun, tidak banyak penelitian yang memfokuskan pada kombinasi sumber pengetahuan seperti literasi teknologi dan literasi keuangan, dan bagaimana pengaruh kombinasi tersebut terhadap kinerja UKM (Mabula \& Dong, 2018). Alasan lain peneliti memilih objek UKM di Kabupaten Lombok Barat karena merupakan salah satu dari wilayah yang memiliki Pelaku Usaha Kecil Menengah (UKM) yang terbilang cukup banyak, serta ketertarikan dari peneliti karena UKM di Kabupaten Lombok Barat menarik untuk diteliti.

Berdasarkan latar belakang di atas penulis tertarik melakukan penelitian yang berjudul "Analisis Pengaruh Techno-finance Literacy dan Praktik Entrepreneur Risk Management terhadap Kinerja Usaha Kecil Menengah (UKM) di Kabupaten Lombok Barat." Pertanyaan Penelitian

Pertanyaan pada penelitian ini adalah "apakah literasi keuangan, literasi teknologi dan praktik ERM berpengaruh terhadap kinerja UKM?"

\section{KAJIAN PUSTAKA}

\subsection{Kinerja UKM}

\subsubsection{Karakteristik dan Definisi kinerja UKM}

Usaha menengah mempunyai aset yang bersih kurang lebih 500 juta sampai 10 milyar dengan penjualan yang paling besar 50 milyar pertahun. Usaha kecil dilaksanakan individu atau pekerja dengan jumlah yang minim. Produk dengan jenis ekonomi dapat berganti sesuai situasi dan kondisi yang ada.

Kendala yang biasanya ditemui oleh para usahawan kecil dan menengah atau UKM adalah (Rizal, 2012:77):

a. Produktivitas yang tergolong masih rendah.

b. Nilai plus yang dalam kategori kebawah.

c. Penanaman modal yang masih sangat minim.

d. Jangkauan pasar yang kecil.

e. Jejaring usaha yang masih terbatas.

f. Jalan masuk ke bahan baku dan asal modal terbatas.

g. Tata kelola masih belum profesional dan SDM yang belum mempunyai mutu untuk maju berkelanjutan.

Kinerja UKM merupakan hasilnya suatu kinerja yang telah diperoleh seseorang serta menepatkan dengan peran dari seseorang pada suatu organisasi dalam kurun waktu tertentu yang terjaring dengan standar tertentu dari organisasi tempat seseorang tersebut bekerja. Pencapaian diukur dengan berhasil tidaknya sesua tujuan perusahaan yang telah ditetapkan (Mutegi dkk, 2015). 


\subsubsection{Pengukuran dan Indikator Kinerja UKM}

Pengukuran kinerja UKM dilakukan dua cara yaitu kinerja keuangan dan kinerja non finansial. Kinerja non finansial adalah kinerja yang menampakkan perkembangan suatu organisasi. Perusahaan mengetahui tingkat keberhasilannya dengan memakai kajian kinerja non finansial.

Menurut Minuzu (2020) Kinerja suatu perusahaan menunjuk pada pencapaiannya dalam kurun waktu tertentu. Indikator yang digunakan untuk mengukur kinerja yaitu:

1. Peningkatan dalam penjualan

2. Peningkatan dalam asset modal

3. Peningkatan tenaga kerja per tahun

4. Peningkatan dari pemasaran dan pasar

5. Peningkatan keuntungan dari suatu usaha

\subsection{Literasi Keuangan}

\subsubsection{Definisi dan indikator literasi keuangan}

Menurut Otoritas Jasa Keuangan (2021), literasi keuangan adalah pemahaman (knowledge), keyakiinan (confidence) dan keahlian (skill) dengan mempengaruhi sikap (attitude) dan perilaku (behaviour) dalam memajukan mutu dari keputusan yang akan diambil dengan dan mengelola finansial agar terciptanya ketentraman suatu perusahaan. Literasi keuangan mencerminkan keterampilan seorang individu untuk mengetahui suatu konsep pada keuangan dan produk jasa finansial serta mengendalikan sumber daya keuangannya pribadi secara individu (Ismanto, 2019).

Menurut OECD (2016) pengukuran dalam literasi keuangan terdapat tiga indikator, yaitu:

a. Pengetahuan keuangam; terkait dengan pengetahuan dasar finansial, manajemen finansial, kredit dan hutang, simpanan dan penanaman modal, resiko, serta asuransi.

b. Perilaku Keuangan; terkait dengan perilaku untuk menyusun rencana finansial, mengontrol dan menghemat finansial, penanaman modal serta membayar kewajiban dengan tepat waktu.

c. Sikap keuangan; terkait pada sikap terhadap finansial dan rencana untuk masa yang akan datang.

\subsubsection{Tingkat Literasi Keuangan}

Menurut OJK (2013), tingkatan literasi keuangan masyarakat di Indonesia terbagi menjadi empat bagian, meliputi:

a. Well literate, mempunyai pemahaman dan kepercayaan mengenai lembaga dan produk jasa finansial, termasuk manfaat dan risiko, kewajiban dan hak, fitur yang terkait produk dan jasa finansial serta mempunyai keterampilan untuk memakai jasa dan produk finansial.

b. Sufficient literate, mempunyai pemahaman dan kepercayaan mengenai lembaga dan produk jasa finansial, termasuk manfaat dan risiko, kewajiban dan hak, fitur yang terkait produk dan jasa finansial.

c. Less literate, mempunyai pemahaman tentang lembaga, produk dan jasa finansial.

d. Not literate, tidak mempunyai pemahaman dan kepercayaan serta keterampilan apapun mengenai finansial

\subsubsection{Literasi Keuangan dan Kinerja UKM}

Literasi keuangan adalah gabungan antara kesadaran dan pengetahuan bisnis dan finansial, kemampuan finansial, manajemen finansial dan perencanaan finansial. Literasi keuangan mencerminkan kemampuan seorang individu agar mengerti tentang konsep finansial, produk dan jasa finansial, dan untuk mengendalikan sumber daya finansial 
secara individu. Semakin baik kemampuan seseorang dalam mengelola literasi keuangannya, maka akan semakin baik pula kinerja suatu UKM yang telah dijalankan oleh seseorang tersebut.

Hal ini mendukung penelitian Suardana dan Musmini (2020) yang mengemukakan bahwa literasi keuangan berpengaruh positif dan signifikan terhadap kinerja UMKM. Penelitian Dayanti (2020) juga mengemukakan bahwa variabel pada literasi keuangan, pengetahuan dan sikap finansial berpengaruh positif dan signifikan terhadap perilaku manajemen finansial. Penelitian Oktara dan Wijayangka (2019) juga menyatakan literasi keuangan berpengaruh signifikan terhadap tumbuhnya suatu UMKM.

H1: Literasi Keuangan Berpengaruh Positif Terhadap Kinerja UKM

\subsection{Literasi Teknologi}

\subsubsection{Definisi Literasi Teknologi}

Menurut Maryland Technology Education State Curriculum, literasi teknologi merupakan keterampilan untuk mengetahui, memproses, menggunakan, serta menilai adanya pembaruan yang melmpengaruhi suatu proses dan ilmu pengetahuan dalam mengendalikan suatu problematika dan membuat luas keterampilan seorang individu. Semakin baik kemampuan individu dalam mengelola literasi teknologi, maka semakin berkembang kinerja suatu UKM yang diempu oleh suatu individu tersebut.

\subsubsection{Literasi Teknologi dan Kinerja UKM}

Literasi teknologi adalah perkembangan literasi dalam teknologi dan cyberspace, dimana berkaitan dengan keterampilan dalam memanfaatkan dan menggunakan media seperti internet untuk mengakses, menyebarluaskan, dan mengkomunikasikan suatu informasi dengan efisien dan efektif. Semakin baik kemampuan individu dalam mengelola literasi teknologi, maka semakin berkembang kinerja suatu UKM yang diempu oleh suatu individu tersebut. Hal ini mendukung penelitian Ilarrahmah dan Susanti (2019) yang mengemukakan bahwa penggunaan teknologi informasi memberikan efek yang positif dan signifikan terhadap kinerja UMKM. Penelitian Utari dan Marini (2014) juga menyatakan tingkat pendidikan dan teknologi berpengaruh positif secara parsial dan signifikan terhadap pendapatan UMKM. Penelitian Wulandari (2019) juga menyatakan bahwa literasi teknologi berpengaruh positif terhadap kinerja usaha konveksi Kabupaten Tulung Agung.

H2 : Literasi Teknologi Berpengaruh Positif Terhadap Kinerja UKM

\subsection{Praktik ERM}

\subsubsection{Definisi Praktik ERM}

Entrepreneur Risk Managemen tmerupakan suatu pengelolaan resiko yang dihadapi oleh perusahaan secara menyeluruh dengan mengintegrasikan semua jenis resiko di seluruh lini bisnis yangbertujuan untuk meningkatkan nilai perusahaan (Hanafi, 2009). ERM juga keterampilan manajemen untuk mengelola resiko dalam bisnis sebagai upaya memperoleh tujuan. Semakin baik suatu perusahaan menerapkan praktik ERM, maka semakin baik juga kinerja UKM dan kredibilitas perusahaan tersebut.

\subsubsection{Praktik Enterprise Risk Management (ERM) dan Kinerja UKM}

Praktik ERM merupakan keterampilan perusahaan dalam pemahaman dan pengendalian tingkatan risiko yang akan diambil dalam pengelolaan rencana usaha, ditambah dengan akuntability resiko yang diambil. ERM juga keterampilan manajemen dalam pengelolaan seluruh risiko bisnis guna upaya mendapatkan suatu tujuan. Semakin baik suatu perusahaan menerapkan praktik ERM, maka semakin baik juga kinerja UKM dan kredibilitas perusahaan tersebut. Hal ini mendukung penelitian Kulathunga, dkk (2020) yaitu praktik ERM berpengaruh positif terhadap kinerja UKM. 


\section{H3 : Praktik ERM Berpengaruh Positif Terhadap Kinerja UKM}

\section{METODE PENELITIAN}

\subsection{Metode pengumpulan data}

Jenis penelitian yang digunakan yaitu asosiatif. Metode pengumpulan datanya adalah sample survey. Populasi yang dipilih dalam penelitian ini adalah seluruh pelaku UKM aktif yang berlokasi di Kabupaten Lombok Barat. Jumlah populasi UKM yang saat ini masih aktif berada di Kabupaten Lombok Barat yaitu 366 UKM.

Penentuan sampel apabila jumlah populasi kurang dari jumlah 100, maka seluruhnya diambil dan digunakan menjadi sampel. Sedangkan jika populasi lebih dari jumlah 100, berarti pengambilan sampel sekitar 10\%-15\% atau lebih (Arikunto, 2002:112). Sampel yang digunakan dalam penelitian ini sebanyak 50 UKM, maka sekitar $14 \%$ dari jumlah 366 populasi yang ada di Kabupaten Lobar. Metode penentuan sampel yang digunakan adalah accidental sampling. Sedangkan, teknik pengumpulan data adalah teknik wawancara dengan menggunakan kuisioner.

\subsection{Variabel Penelitian}

Variabel pada penelitian ini terdiri dari variabel bebas (literasi keuangan, literasi teknologi, dan paraktek ERM) dan variabel terikat (kinerja UKM). Variabel diukur dengan menggunakan 7 skala likert.

Literasi Keuangan adalah pemahaman dan kemampuan masyarakat untuk mengelola finansialnya dengan cara memahami perbankan, investasi, membuat rencana finansial dan membuat tabungan pribadi yang bertujuan membantu kondisi keuangan seseorang agar tetap stabil. Indikator literasi keuangan dalam penelitian ini adalah knowledge, behavior, skill dan attitude.

Literasi Teknologi adalah kemampuan dalam mengembangkan teknologi dengan memanfaatkan media seperti internet untuk menyebarkan, mengakses dan mengupayakan dalam efektivitas komunikasi informasi. Indikator literasi teknologi dalam penelitian ini adalah Infrastruktur ICT (Information and Communication Technology) dan Aplikasi ICT (Information and Communication Technology).

Entrepreneur Risk Management merupakan kemampuan suatu perusahaan dalam pemahaman dan pengendalian resiko guna mengelola suatu rencana bisnis. Indikator ERM dalam penelitian ini adalah risiko dan peluang. Resiko adalah menyimpangnya suatu hal yang diharapkan, sedangkan peluang dalam usaha adalah seluruh ide bisnis dan perencanaan, serta kesempatan dari suatu usaha yang sedang dikembangkan atau baru dimulai.

\subsection{Prosedur Analisis Data}

Alat analisis data dalam penelitian ini adalah model analisis regresi linier berganda, untuk melihat pengaruh literasi keuangan, literasi teknologi, dan paraktek ERM terhadap kinerja UKM.

\section{HASIL DAN PEMBAHASAN}

Gambaran data penelitian yaitu hasil tersebarnya kuisioner secara serentak kepada responden yaitu UKM yang bergerak pada sektor ekonomi kreatif di Kabupaten Lombok Barat. Jumlah kuisioner yang disebar adalah 50 dan dari 50 kuesioner yang disebar tersebut seluruh datanya dapat diolah atau dianalisis lebih lanjut. 


\subsection{Analisis Regresi Linier Berganda}

Hasil analisis data menggunakan regresi liner berganda yang ditunjukkan pada Tabel 1 berikut.

Tabel 1. Hasil analisis regresi berganda

\begin{tabular}{|l|r|c|c|c|}
\hline \multicolumn{1}{|c|}{ Variabel } & \multicolumn{1}{c|}{ B } & Beta & t & Sig. \\
\hline Konstanta & \multicolumn{1}{c|}{26.103} & & 14.755 & 0.000 \\
\hline $\begin{array}{l}\text { Literasi } \\
\text { Keuangan }\end{array}$ & 0.017 & 0.043 & 0.254 & 0.801 \\
\hline $\begin{array}{l}\text { Literasi } \\
\text { Teknologi }\end{array}$ & 0.135 & 0.264 & 1.585 & 0.120 \\
\hline Praktik ERM & 0.368 & 0.360 & 2.149 & $0.037^{*}$ \\
\hline R square & 0,356 & \multicolumn{3}{|l}{} \\
\hline
\end{tabular}

Note: Signifikan pada tingkat signifikansi 95\%

Berdasarkan tabel diatas maka dari itu diperoleh model pada persamaan regresi linier berganda yaitu:

$$
\hat{y}=26.103+0.017 X_{1}+0.135 X_{2}+0.368 X_{3}
$$

Persamaan regresi linier berganda tersebut dapat dijelaskan sebagai berikut:

a. Konstanta sebesar 26,103 artinya apabila literasi keuangan, literasi teknologi dan praktik ERM sama dengan nol, maka kinerja UKM sebesar 26,103.

b. Koefisien regresi variabel literasi keuangan sebesar 0,017 artinya jika literasi keuangan bertambah satu persen, maka kinerja UKM akan bertambah sebesar 0,017 kali.

Variabel literasi keuangan tidak signifikan secara parsial berpengaruh terhadap variabel kinerja UKM

c. Koefisien regresi variabel literasi teknologi sebesar 0,135 artinya jika literasi teknologi bertambah satu persen, maka kinerja UKM akan bertambah sebesar 0,135 kali.

Variabel literasi teknologi tidak signifikan berpengaruh secara parsial terhadap variabel kinerja UKM

d. Koefisien regresi variabel praktik ERM sebesar 0,368 artinya apabila praktik ERM bertambah satu persen, maka kinerja UKM akan bertambah 0,368 kali.

Variabel praktik ERM signifikan berpengaruh secara parsial terhadap variabel kinerja UKM.

\subsection{Koefisien Determinasi}

Berdasarkan Tabel 1 menunjukkan bahwa nilai $\mathrm{R}^{2}$ sebesar 0.356 atau 35.6\%, artinya variabel literasi keuangan, literasi teknologi dan praktik ERM mampu menjelaskan variabel kinerja UKM sebesar $35.6 \%$ sisanya $64.4 \%$ terdapat variabel lain yang mampu menjelaskan kinerja UKM.

\subsection{Analisis dan Pembahasan}

\subsubsection{Pengaruh Literasi Keuangan terhadap Kinerja UKM}

Literasi Keuangan (X1) memiliki pengaruh yang positif tetapi tidak signifikan terhadap kinerja UKM, dengan koefisien regresi positif dan nilai sig diatas alpha yang artinya walaupun semakin tinggi tingkat literasi keuangan pelaku UKM di Kabupaten Lombok Barat tetapi masih belum cukup untuk meningkatkan kinerja UKM. Dan ketika literasi keuangan pelaku UKM di Kabupaten Lombok Barat menurun, juga tidak akan mempengaruhi kinerja UKM. Sehingga hasil pada penelitian ini dapat dikatakan menolak hipotesis pertama yang berasumsi bahwa Literasi Keuangan berpengaruh positif terhadap kinerja UKM. 
Deskripsi data hasil kuisioner memperlihatkan variabel literasi keuangan termasuk dalam kategori rendah, dimana dengan literasi keuangan yang rendah menyebabkan tidak berpengaruh terhadap kinerja UKM. Literasi keuangan dapat memberikan fasilitas pengambilan suatu keputusan seperti tagihan yang dibayar tepat waktu, manajemen hutang yang baik dapat membuat nilai kredit dari potensi peminjam untuk menunjang kinerja usaha meningkat. Literasi keuangan adalah salah satu faktor bagi perusahaan dalam membuat suatu keputusan namun tidak berpengaruh signifikan terhadap kinerja UKM, dimana perusahaan menganggap literasi keuangan belum cukup baik dalam pengambilan keputusan dengan risiko yang akan ditanggungnya.

\subsubsection{Pengaruh Literasi Teknologi terhadap Kinerja UKM.}

Literasi Teknologi (X2) memiliki pengaruh positif tetapi tidak signifikan terhadap kinerja UKM, dengan koefisien regresi positif dan nilai sig diatas alpha artinya walaupun semakin tinggi tingkat literasi teknologi pelaku UKM di Kabupaten Lombok Barat tetapi masih belum cukup untuk meningkatkan kinerja UKM. Dan ketika literasi teknologi pelaku UKM di Kabupaten Lombok menurun, juga tidak akan mempengaruhi kinerja UKM. Sehingga hasil penelitian ini dapat dikatakan bahwa menolak hipotesis kedua yang berasumsi bahwa Literasi Teknologi berpengaruh positif terhadap kinerja UKM.

Deskripsi data hasil kuisioner memperlihatkan variabel literasi teknologi termasuk dalam kategori rendah, dimana dengan literasi teknologi yang rendah menyebabkan tidak berpengaruhnya terhadap kinerja UKM. Literasi teknologi dapat memberikan fasilitas untuk menyokong kinerja dalam mencapai dan mempertahankan keunggulan kompetitif. Literasi teknologi adalah salah satu faktor bagi perusahaan dalam membuat strategi namun tidak berpengaruh signifikan terhadap kinerja UKM, dimana perusahaan menganggap literasi teknologi belum cukup baik dalam meningkatkan produktivitas yang dicapai perusahaan.

\subsubsection{Pengaruh Praktik ERM terhadap Kinerja UKM}

Praktik ERM (X3) memiliki pengaruh positif dan signifikan terhadap kinerja UKM, dengan koefisien regresi positif dan nilai sig dibawah alpha artinya semakin tinggi praktik ERM pelaku UKM di Kabupaten Lombok Barat maka akan semakin tinggi juga kinerja UKM. Dan ketika praktik ERM menurun, akan mengakibatkan menurunnya Kinerja UKM. Sehingga hasil penelitian ini dapat dikatakan bahwa menerima hipotesis ketiga yang berasumsi bahwa Praktik ERM berpengaruh positif terhadap kinerja UKM.

Deskripsi data hasil kuisioner memperlihatkan variabel praktik ERM termasuk dalam kategori rendah, dimana dengan praktik ERM yang belum maksimal menyebabkan hubungannya dengan kinerja UKM dalam kategori tinggi yang berarti praktik ERM berpengaruh terhadap kinerja UKM. Praktik ERM merupakan pemahaman suatu organisasi dalam memahami dan mengendalikan tingkat risiko yang diambil dalam pengelolaan rencana bisnis, ditambah dengan akuntabilitas atas resiko yang diambil. Dengan adanya praktik ERM merupakan salah satu faktor bagi perusahaan di dalam mengendalikan tingkat risiko dalam pengambilan keputusan suatu perusahaan dan berpengaruh signifikan secara parsial terhadap kinerja UKM.. Hasil penelitian ini sejalan dengan hasil penelitian yang dilakukan Kulathunga, dkk (2020) yaitu praktik ERM berpengaruh positif terhadap kinerja UKM.

\section{KESIMPULAN DAN SARAN}

Berdasarkan hasil analisis dan pembahasan diatas mengenai pengaruh literasi keuangan, literasi teknologi dan praktik ERM terhadap kinerja UKM maka dapat ditarik kesimpulan sebagai berikut: 
1. Literasi keuangan berpengaruh positif tetapi tidak signifikan terhadap kinerja UKM.

2. Literasi teknologi berpengaruh positif tetapi tidak signifikan terhadap kinerja UKM.

3. Praktik ERM berpengaruh positif dan signifikan terhadap kinerja UKM.

Berdasarkan hasil analisis pembahasan serta beberapa kesimpulan diatas maka penulis memberikan saran sebagai berikut:

1. Peneliti selanjutnya disarankan untuk meningkatkan variabel Praktik ERM, karena walaupun praktik ERM dalam kategori rendah tetapi menyebabkan tingginya kinerja UKM.

2. Bagi peneliti selanjutnya diharapkan untuk mencoba literasi keuangan dan literasi teknologi sebagai moderasi karena tidak berpengaruh secara langsung terhadap kinerja UKM.

\section{DAFTAR PUSTAKA}

Ates, Aylin and Bititici. 2007. Strategi management in small to medium-sized enterprises: Evidence from UK manufacturing SMEs. Strathclyde institute for Opeation Management, University of Strathclyde, Glasgow UK.

Amisi, S. (2012). The Effect of Financial Literacy on Investment Decision Making by Pension Fund Managers in Kenya. Oct, 1-74.

Anggraeni, B. D. 2016. Pengaruh Tingkat Literasi Keuangan Pemilik Usaha terhadap Pengelolaan Keuangan. Studi Kasus: UMKM Depok. Jurnal Vokasi Indonesia, Vol.3 No.1, 22-30.

Aribawa, Dwitya. 2016. Pengaruh Literasi Keuangan terhadap Kinerja Dan Keberlangsungan UMKM di Jawa Tengah. Jurnal Siasat Bisnis. 20(1). 1-13

Aulia, Ridho. 2020. Bangkit dari Pandemi ala Lombok. https:// www.medcom.id/telusur/medcom-files/gNQ5j8nN-bangkit-daripandemi-ala-lombok-barat (diakses pada 10 Februari 2022)

Barbara Beshel, An Introduction to Franchising, IFA Educational Foundation, www.themoneyinstitute2000.com

Kuncoro, Haryo. 2002. Upah Sistem Bagi Hasildan Penyerapan Tenaga Kerja, Jurnal Ekonomi Pembangunan, Vol 7 Nomor 1: 45-54.

Sanistasya, P. A., Raharjo, K., \& Iqbal, M. (2019). The Effect of Finance Literacy and Finance Inclusion on Small Enterprises Performance in East Kalimantan. Jurnal Economia, 15(1), 48-59. https://journal.uny.ac.id/index.php/economia/article/view/23192

Nasution, 2014, Hukum Perlindungan Konsumen di Indonesia, Bandung: PT. Citra Adiya Bakti

Baswir, Revrisond. Koperasi Indonesia. Yogyakarta : BPFE-Yogyakarta, 2010.

Dhea. 2021. Lombok Barat Gelar Pelatihan Kewirausahan Bagi Penyandang Disabilitas. https://diskopukm.lombokbaratkab.go.id/berita/lombok-barat-gelar-pelatihankewirausahaan-bagi-penyandang-disabilitas/ (diakses pada 10 Februari 2022)

Djojosoedarso, S. 2003. Prinsip-Prinsip Manajemen Resiko dan Asuransi, Edisi. Revisi. Jakarta: Salemba Empat.

Garg, N., \& Singh, S. (2018). Financial literacy among youth. International Journal of Social Economics, 45(1), 173-186. https:/ / doi.org/10.1108/IJSE-11-2016-0303

Hanafi, M.M. 2009. Manajemen Risiko. Unit Penerbit dan Percetakan Sekolah Tinggi Ilmu Manajemen YKPN: Yogyakarta

Her. 2020. Bantuan untuk UMKM Lobar Mulai Dicairkan. Suara NTB. https://www.suarantb.com/bantuan-untuk-umkm-di-lobar-mulai-dicairkan/ (diakses pada 10 Februari 2022) 
Hery. 2015. Analisis Laporan Keuangan. Edisi 1. Yogyakarta: Center for Academic Publishing Services.

Ismanto., Widiastuti., Muharam., Pangestuti dan Rofiq. (2019). Perbankan dan Literasi Keuangan. Yogyakarta: CV Budi Utama.

Monica Dewi Ilarrahmah dan Susanti. (2019). “Pengaruh Kemampuan Menyusun Laporan Keuangan, Literasi Keuangan Dan Penggunaan Teknologi Informasi Terhadap Kinerja UMKM". JPEK (Jurnal Pendidikan Ekonomi dan Kewirausahaan).

Mutegi, H. K., Njeru, P. W., dan Ongesa, N. T. 2015. Financial Literacy and Its Impact On Loan Repayment by Small And Medium Entreprenurs. International Journal of Economics, Commerce and Management, Vol. 3( Issue 3), 1-28.

OECD. (2016). PISA 2015 Assessment and Analytical Framework: Science, Reading, Mathematic and Financial Literacy, PISA, OECD Publishing, Paris.

Otoritas Jasa Keuangan. 2013. Indonesia National Strategy for Financial Literacy, (Online), https:// sikapiuangmu.ojk.go.id/.

Silalahi, Harini Triana, 2016, "Studi Komparasi Tingkat Literasi Keuangan Keluarga di Desa Congcatur, Yogyakarta Ditijau dari Status Sosial Ekonomi dan Gaya Hidup" Universitas Sanata Dharma, Yogyakarta 